\title{
Analgesic and Anti-inflammatory Effect of Clausena suffruticosa Root Extract in Animal Model
}

\author{
J. S. Chakma1, M. A. Rahman ${ }^{1 *}$, S. Islam², M. S. Rana ${ }^{1}$, and N. U. Ahmed ${ }^{2}$ \\ ${ }^{1}$ Department of Biochemistry and Molecular Biology, University of Chittagong, Chittagong-4331, \\ Bangladesh \\ ${ }^{2}$ Bangladesh Council of Scientific and Industrial Research (BCSIR), Chittagong, Bangladesh
}

Received 8 May 2011, accepted in final revised form 5 August 2011

\begin{abstract}
The aim of the study was to evaluate the analgesic and anti-inflammatory effects of C. suffruticosa root extract. The effect of different concentrations of ethanolic root extract were studied in animal model using acetic acid induced writhing response, formalin induced pain, hot plate method for analgesic activity in Swiss Albino mice and carrageenan induced paw edema for anti-inflammatory action in Wister Albino rat. The extract reduced writhing response $20 \%$ by $0.5 \mathrm{~g} / \mathrm{kg}, 57.6 \%$ by $1.5 \mathrm{~g} / \mathrm{kg}$ and $78 \%$ by $2 \mathrm{~g} / \mathrm{kg}$ and showed significant analgesic activity as determined by formalin induced pain and hot plate method. In the carrageenan induced paw edema, the extract at a dose of $0.5,1.0$ and $2.0 \mathrm{~g} / \mathrm{kg}$ showed the highest inhibition $17.23 \%, 26.30 \%$ and $42.46 \%$, respectively, at the $4^{\text {th }}$ hour of administration. The results indicate that the extract shows promising analgesic effect in chemical models of nociception (not related to the opioid system) and anti-inflammatory effect.
\end{abstract}

Keywords: Analgesic; Anti-inflammatory; Clausena suffruticosa; Ethanolic extract.

(C) 2011 JSR Publications. ISSN: 2070-0237 (Print); 2070-0245 (Online). All rights reserved. doi:10.3329/jsr.v3i3.7594 J. Sci. Res. 3 (3), 631-639 (2011)

\section{Introduction}

The plant Clausena suffruticosa, popularly known as Sadi urisha has been used in traditional Chakma herbal medicine. It is rarely distributed in Chittagong Hill Tracts of Bangladesh, Eastern Himalayan regions, Kashi Hill of India and Burma. Different parts of this plant have been used for some chronic disease like paralysis, tumors and diseases related to kidney and liver, pain, bleeding and fever. It is also used for mumps, viral pneumonia, cerebrospinal meningitis etc. Paste of $C$. suffruticosa root had been used traditionally in rheumatoid arthritis since long but no work has been undertaken to confirm its analgesic and anti-inflammatory activity. Therefore, the study was designed to evaluate the analgesic and anti-inflammatory potentials of ethanolic extracts of C. suffruticosa root.

\footnotetext{
*Corresponding author: atiarh@yahoo.com
} 


\section{Material and Methods}

\section{Collection of plant material}

Plant materials were collected from various region of Khagrachari District, Chittagong Hill Tracts of Bangladesh. The plant was taxonomically identified by Dr. Md. Mostafa Kamal Pasha (Professor and Taxonomist, Department of Botany, University of Chittagong, Bangladesh.) A voucher sample has been deposited at the Bangladesh National Herbarium, Ministry of Environment and Forest, Dhaka, with an accession no. dacd-32909.

\section{Preparation of extracts}

The fresh roots of $C$. suffruticosa were chopped into small pieces, air dried at room temperature for ten days and pulverized into powder $(1 \mathrm{~kg})$. Root powder $(1 \mathrm{~kg})$ was extracted with ethanol, being stirred and macerated at room temperature $(23 \pm 5)^{0} \mathrm{C}$ for 7 days. The filtered ethanol was evaporated under reduced pressure below $50^{\circ} \mathrm{C}$ through rotatory vacuum evaporator (RE200 Sterling, UK). The concentrated extract (45g) was stored at $4^{\circ} \mathrm{C}$ until further use.

\section{Experimental animal and diet}

Swiss albino mice of either sex weighting between 25 to $30 \mathrm{gm}$ and Wister albino rats of the both sex weighing between 150-200g obtained from animal house of Bangladesh Council of Scientific and Industrial Research (BCSIR) laboratories, Chittagong were used in this study. The animals were acclimatized at room temperature $(28 \pm 5)^{0} \mathrm{C}$ with a relative humidity of $55 \pm 5 \%$ in a standard wire meshed plastic cages for 4 to 5 days prior to commencement of the experiment. During the entire period of study the animals were supplied standard pellet diet and water ad libitum. All animal experimentations were carried out with the guidelines of Institutional Animal Ethics Committee (IAEC).

\section{Acetic acid induced writhing test}

The abdominal constriction was induced in mice (weighing 25-30g) by intraperitoneal injection of $1 \%(\mathrm{v} / \mathrm{v})$ acetic acid $(2.3 \mathrm{ml} / \mathrm{kg})$, as described by Koster et al. 1959 [1]. Animals were pre-treated with the ethanol extracts of C. suffruticosa (0.5, 1.5 and 2.0 $\mathrm{g} / \mathrm{kg}) 30$ minutes before acetic acid administration. Control animals received a $2 \mathrm{ml}$ volume of distilled water and the positive control animals were treated with reference analgesic drug diclofenac sodium $(40 \mathrm{mg} / \mathrm{kg})$. The number of abdominal constriction was cumulatively counted over a period of 20 minute. The percentage inhibition of analgesic activity was calculated using following formula:

$$
\% \text { Analgesic activity }=\frac{\text { Mean writing count (control group-treated group) }}{\text { Mean writhing count of control group }} \times 100
$$




\section{Formalin test}

The procedure was similar to that described previously by Gaertner et al. [2]. The ethanol extracts of $C$. suffruticosa $(0.5,1.0$ and $2.0 \mathrm{~g} / \mathrm{kg})$, reference analgesic drug diclofenac sodium $(40 \mathrm{mg} / \mathrm{kg})$ and distilled water were administered orally 30 minutes before formalin injection. $20 \mu \mathrm{l}$ of $2.5 \%$ formalin $(0.92 \%$ formaldehyde) made in phosphate buffer was injected under the right hind paw surface of experimental mice. Each mouse was placed individually in a case and observed from 0 to $5 \mathrm{~min}$ followed by the injection of formalin to analyze the first phase (neurogenic pain) and 15 to $40 \mathrm{~min}$ to analyze the second phase (nociceptive pain) of formalin induced pain. The length of time the animal spent licking the injected paw was recorded with a chronometer and was considered as indicative of pain.

\section{Hot plate method}

Thermal pain test in mice was done by following the hot plate method [3]. Mice were placed on an enclosed hot plate (Scored DS37, UGO Basile, Italy) maintained at temperature $(54 \pm 0.5)^{0} \mathrm{C}$. Animals presenting response (licking of the hind paw or jumping) $>15$ seconds were discarded. The cut-off time of $30 \mathrm{sec}$ was used to prevent tissue damage. Prior to dosing, the reaction times were measured and were used as the pre-drug latency. Mice (five per group) were administered (intra peritoneal) with $C$. suffruticosa root extract $(0.5,1.5$ and $2.0 \mathrm{~g} / \mathrm{kg}$ ) and morphine $(5 \mathrm{mg} / \mathrm{kg}$, i.p.). Then at 30 minutes intervals the reaction time was measured till $120^{\text {th }}$ minutes of treatment and used as post-drug latency. Observation started after $30 \mathrm{~min}$ of administration of the test substances except for morphine which was 15 min after administration. The percent of maximum possible effect (\%MPE) was determined according to the formula [4]:

$$
\% \mathrm{MPE}=\frac{\text { Post-treatment latency }- \text { Pre-treatment }}{\text { Cut-off time- Pre-treatment latency }} \times 100
$$

\section{Carrageenan-induced paw edema test}

Ant-inflammatory activity of $C$. suffruticosa root extracts was assessed by carrageenan paw edema model of rats by the reported method of Winter et. al. [5]. According to winter, acute inflammation (paw edema) was induced in albino rats by subplantar injection of $100 \mu \mathrm{l}$ of $1 \%(\mathrm{w} / \mathrm{v})$ carrageenan after measuring the initial right hind paw volume of each rat. The volume of right hind paw was measured at $1^{\text {st }}, 2^{\text {nd }}, 3^{\text {rd }}$ and $4^{\text {th }}$ hour after carrageenan injection and the paw edema was determined using plethysmometer (7150 UCG, Basil, Italy). C. suffruticosa root extracts (0.5, 1.0 and $2 \mathrm{~g} / \mathrm{kg}$ ), standard antiinflammatory drug diclofenac sodium $(40 \mathrm{mg} / \mathrm{kg})$ and distilled water were administered orally to treated, positive control and control groups 1 hour before the subplanter injection of carrageenan. The inhibitory activity was calculated according to the following formula [6].

$$
\text { Percentage inhibition }=\frac{\left(\mathrm{C}_{\mathrm{t}}-\mathrm{C}_{0}\right) \text { control- }\left(\mathrm{C}_{\mathrm{t}}-\mathrm{C}_{0}\right) \text { treated }}{\left(\mathrm{C}_{\mathrm{t}}-\mathrm{C}_{0}\right) \text { control }} \times 100
$$




\section{Analgesic and Anti-inflammatory}

\section{Statistical analysis}

Value for analgesic activity was expressed as "mean increase in latency after drug administration \pm SEM" in term of seconds whereas values for anti-inflammatory activity were expressed as "mean increase in paw volume \pm SEM". The significance of difference between means was determined by student's t-test value of $P<0.05$ were significant and $P<0.01$ and $P<0.001$ as highly significant.

\section{Results}

The results obtained with acetic acid induced writhing are shown in Table 1. All dose administered (0.5, 1.5 and $2.0 \mathrm{gm} / \mathrm{kg})$ had a significant $(P<0.001$ and $P<0.05)$ effects on the number of abdominal contractions, promoting 20\%, 57.6\% and $78 \%$ inhibition, respectively, as compared with the control group treated with distilled water. Diclofenac sodium at a dose of $40 \mathrm{mg} / \mathrm{kg}$ showed $74.80 \%$ inhibition.

Table 1. Effect of $C$. suffruticosa root extract on acetic acid induced writhing response in mice.

\begin{tabular}{lcccc}
\hline Groups $(n=10)$ & $\begin{array}{c}\text { Writhing response } \\
\text { (count/20mins) }\end{array}$ & $\begin{array}{c}\text { \% of analgesic } \\
\text { effect }\end{array}$ & \multicolumn{2}{c}{ Student's t-test } \\
$t$-calculated & $t$-tabulated \\
\hline Control & $62.50 \pm 4.42$ & - & - & - \\
CSEx $0.5 \mathrm{gm} / \mathrm{kg}$ & $50.00 \pm 2.48^{*}$ & 20.0 & 2.46 & 2.45 \\
CSEx $1.5 \mathrm{gm} / \mathrm{kg}$ & $26.50 \pm 2.02^{* *}$ & 57.6 & 7.40 & 5.95 \\
CSEx $2.0 \mathrm{gm} / \mathrm{kg}$ & $13.75 \pm 2.25^{* *}$ & 78.0 & 12.25 & 5.95 \\
DS & $15.75 \pm 2.25^{* *}$ & 74.8 & 21.10 & 5.95 \\
\hline
\end{tabular}

CSEx: Clausena suffruticosa extract; DS: Diclofenac sodium.

All the values of writhing responses are expressed as mean $\pm \operatorname{SEM}(n=5)$.

** $P<0.001$ and $* P<0.05$ significant compared to control (Student's t-test).

Results for formalin test are summarized in Table 2. The root extracts showed a promising antinociceptive action against both in the early and the late phase of formalin induced pain. The lowest dose $(0.5 \mathrm{~g} / \mathrm{kg})$ showed significant $(* P<0.01)$ inhibition $(11.55 \%)$ while two other doses $(1.0 \mathrm{~g} / \mathrm{kg}$ and $2.0 \mathrm{~g} / \mathrm{kg}$ ) exerted very significant $(* * P<$ 0.001 ) inhibition (25.53\% and 54.30\%) in the early phase of extract administration. In the late phase, $0.5 \mathrm{~g} / \mathrm{kg}$ promoted $2.04 \%, 1.0 \mathrm{~g} / \mathrm{kg}$ achieved $13.20 \%$ and $2.0 \mathrm{~g} / \mathrm{kg}$ achieved $27.49 \%$ inhibition of licking response. All the values were very significant $(* * * P<$ 0.001). Morphine reduced the licking time to show the inhibition $53.69 \%$ in the early phase and $71.77 \%$ in the late phase. 
Table 2. Effect of $C$. suffruticosa root extract and morphine in \% reduction of licking response.

\begin{tabular}{lcccc}
\hline & \multicolumn{4}{c}{ Paw licking time } \\
\hline Group & First phase & $\begin{array}{l}\text { Inhibition } \\
(\%)\end{array}$ & $2^{\text {nd }}$ phase & $\begin{array}{l}\text { Inhibition } \\
(\%)\end{array}$ \\
\hline Control (Dist. $\left.\mathrm{H}_{2} \mathrm{O}\right)$ & $72.44 \pm 0.33$ & - & $188.50 \pm 0.87$ & - \\
CSEx $0.5 \mathrm{~g} / \mathrm{kg}$ & $67.30 \pm 0.21^{*}$ & 7.09 & $184.66 \pm 0.58^{* *}$ & 2.04 \\
CSEx $1.0 \mathrm{~g} / \mathrm{kg}$ & $54.68 \pm 0.20^{* *}$ & 24.51 & $163.63 \pm 0.59^{* *}$ & 13.20 \\
CSEx $2.0 \mathrm{~g} / \mathrm{kg}$ & $42.91 \pm 0.32^{* *}$ & 40.76 & $136.69 \pm 1.00^{* *}$ & 27.49 \\
Morphine $5 \mathrm{mg} / \mathrm{kg}$ & $33.54 \pm 0.20^{* *}$ & 53.69 & $122.32 \pm 0.75^{* *}$ & 35.11 \\
\hline
\end{tabular}

Here, all values are expressed as mean \pm SEM $(n=5)$.

$* P<0.01$ significant compared to control.

** $P<0.001$ significant compare to control.

In the hot-plate test, $C$. suffruticosa root extract increased the latency time (Fig. 1) for nociception above the control value throughout the period of observation. Highest latency as well as \%MPE was observed at $30^{\text {th }} \mathrm{min}$ at dose level $2.0 \mathrm{~g} / \mathrm{kg}$ body weight.

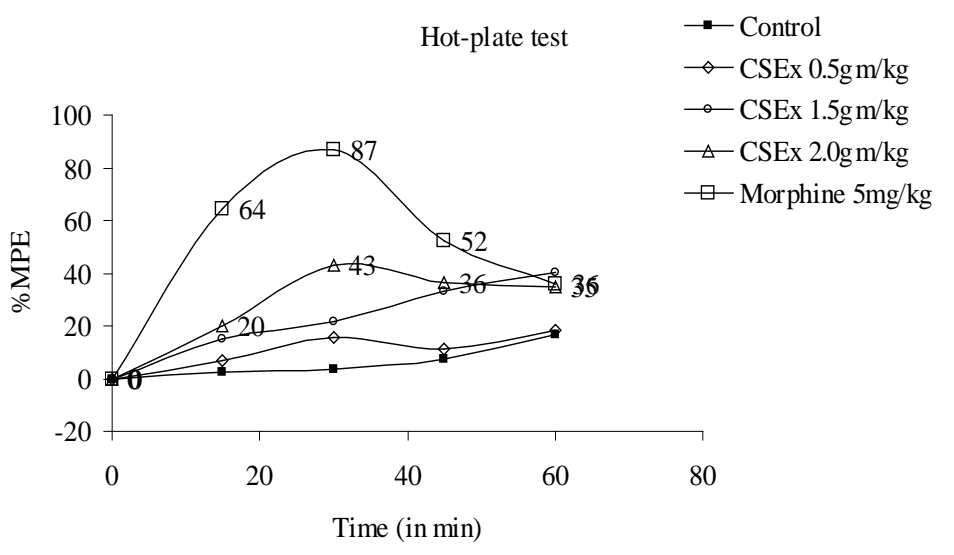

Fig. 1. Maximum possible effect (\%MPE) of different doses of $C$. suffruticosa root extract.

In carrageenan induced paw edema test, intraperitonial injection of carrageenan in rats showed a time depended increase in paw thickness. The maximum increase was observed at the $4^{\text {th }}$ of carrageenan administration in the control group (Table 3). C. suffruticosa extract at a concentration of $0.5 \mathrm{~g} / \mathrm{kg}$ promoted the reduction of paw edema $14.8 \%$ at the $3^{\text {rd }} \mathrm{hr}$ and $17.23 \%$ at the $4^{\text {th }} \mathrm{hr}$ of carrageenan administration. Whereas, the dose $1.0 \mathrm{~g} / \mathrm{kg}$ and $2.0 \mathrm{~g} / \mathrm{kg}$ reduced the paw edema $26.30 \%$ and $42.46 \%$, respectively at the $4^{\text {th }} \mathrm{hr}$ of 
carrageenan injection (Table 4). However, carrageenan induced inflammation was significantly $\left(* P<0.05\right.$ and $\left.{ }^{* *} P<0.01\right)$ ) reduced in all phases of the experiment by the treatment with reference anti-inflammatory drug diclofenac sodium $(40 \mathrm{mg} / \mathrm{kg})$ with compared to control. Diclofenac sodium produced 38.71\%, 45.67\%, 58.32\% and $60.88 \%$ of anti-inflammatory effects at the $1^{\text {st }}, 2^{\text {nd }}, 3^{\text {rd }}$ and $4^{\text {th }}$ hr after carrageenan injection, respectively.

Table 3. Effects of $C$. suffruticosa root extract in carrageenan induced hind paw in rat.

\begin{tabular}{ccccc}
\hline Group & \multicolumn{4}{c}{ Hind paw edema $\left(\mathrm{mm}^{3}\right)$} \\
\cline { 2 - 5 } & $1 \mathrm{~h}$ & $2 \mathrm{~h}$ & $3 \mathrm{~h}$ & $4 \mathrm{~h}$ \\
\hline $\begin{array}{c}\text { Control (Dist. } \\
\left.\mathrm{H}_{2} \mathrm{O}\right)\end{array}$ & $0.37 \pm 0.04$ & $0.63 \pm 0.05$ & $0.76 \pm 0.06$ & $0.88 \pm 0.11$ \\
CSEx $0.5 \mathrm{~g} / \mathrm{kg}$ & - & $0.55 \pm 0.004$ & $0.65 \pm 0.01$ & $0.73 \pm 0.04$ \\
CSEx $1.0 \mathrm{~g} / \mathrm{kg}$ & $0.35 \pm 0.004$ & $0.51 \pm 0.005$ & $0.58 \pm 0.01^{*}$ & $0.65 \pm 0.008$ \\
CSEx $2.0 \mathrm{~g} / \mathrm{kg}$ & $0.34 \pm 0.04$ & $0.38 \pm 0.04^{* *}$ & $0.4 \pm 0.03^{* *}$ & $0.48 \pm 0.02^{*}$ \\
DS $40 \mathrm{mg} / \mathrm{kg}$ & $0.22 \pm 0.04^{*}$ & $0.34 \pm 0.07^{*}$ & $0.31 \pm 0.03^{* *}$ & $0.34 \pm 0.04^{* *}$ \\
\hline $\begin{array}{l}\text { All the values are expressed as MEAN } \pm \text { SEM }(n=4) . \\
* * P<0.01 \text { significant compare to control. }\end{array}$ & & \\
$* P<0.05$ significant compare to control.
\end{tabular}

Table 4. \% of anti-inflammatory effect of $C$. suffruticosa root extract and diclofenac sodium in rat.

\begin{tabular}{lcccc}
\hline Group & \multicolumn{4}{c}{ \% Inhibition of paw edema } \\
\cline { 2 - 5 } & $1^{\text {st }}$ hour & $2^{\text {nd }}$ hour & $3^{\text {rd }}$ hour & $4^{\text {th }}$ hour \\
\hline Control (Dist. $\left.\mathrm{H}_{2} \mathrm{O}\right)$ & - & - & - & - \\
CSEx 0.5gm/kg & - & 13.38 & 14.8 & 17.23 \\
CSEx 1.0 gm/kg & 5.40 & 19.68 & 24.07 & 26.30 \\
CSEx 2.0 gm/kg & 7.80 & 39.53 & 42.46 & 42.46 \\
Positive control (DS) & 38.71 & 45.67 & 58.32 & 60.88 \\
\hline
\end{tabular}

\section{Discussion}

The present study shows that ethanol roots extract significantly reduced acetic acid induced writhing response and attenuated the nociception produced by formalin injection. The acetic acid writhing test was normally used to study the peripheral antinociceptive effects of drugs. Although, this test is a nonspecific model (e.g. anticholinergic and 
antihistaminic and other agents also showed activity in this test), it was widely used for antinociceptive screening. According to Nguelefack et al. [7], acetic acid induces writhing through the release of pain mediators such as histamines, serotonin, and prostaglandins or by direct stimulation of acid sensitive receptors. Active substances against this pain model may interfere with one of these mediator systems or may act on the central nervous system (CNS) by blocking the pain influx transmission. Ethanol extracts of $C$. suffruticosa dose dependently and significantly reduced the writhing responses of mice. Therefore, it could be acting peripherally on the mediator system or on the CNS.

In order to assay whether $C$. suffruticosa possesses central or peripheral analgesic effect, it was further tested on pain induced by formalin. Injection of formalin under the subaponeurotic space of the hind paws causes pain with two phases. The first phase or neurogenic phase, is due to the release of substance $P$ and it is followed by a second phase or inflammatory phase, which is characterized by the release of serotonin, histamine, bradykinin, and prostaglandins [2, 8, 9]. Diclofenac sodium, a well known NSAID inhibits only the 2nd phase of this pain model, while central analgesics inhibit both phases $[10,11]$. C. suffruticosa extract significantly inhibited both phases, which suggests that, it possesses central analgesic activity, but could possess peripheral activity since the effect was higher in the 2nd phase.

In the hot plate test, a central model that has a selectivity for opioid-derived analgesics [12], intraperitoneal treatment with $C$. suffruticosa root extract showed a potent antinociceptive effect on the acute noxious thermal stimulation and confirming the central activity of this extract. In this test, pre-treatment with morphine reversed this antinociceptive effect confirming that this effect is produced by activation of the opioid system.

In addition, as shown in Table 3, the extract has significant anti-inflammatory effects. Anti-inflammatory activity through carrageenan induced paw edema is a suitable test for evaluating anti-inflammatory properties for natural drugs because it shows very promising sensitivity, particularly in the acute phase of inflammation [13-15], in detecting orally active anti-inflammatory agents. Development of edema in paw of rat after injection of carrageenan is a discrete biphasic event, the initial phase of which is observed during the first hour attributed to the release of histamine and serotonin whereas the second phase of edema is due to the release of prostaglandins, prostate and lysosome. This leads to a dilation of the arterioles and venules and to an increased vascular permeability. As a consequence, fluid and plasma proteins are extravagated and edema forms. The mediators, including histamine, 5-HT, the kinins and their components, therefore, have become the recent focus of attention as they are the metabolites of arachidonic acid (AA). Alone or in appropriate combination, AAs are capable of producing the characteristic signs of inflammation which subsequently produces vasodilatation, hyperemia, pain, edema and cellular filtration.

Qualitative analysis of extracts of root from C. suffruticosa revealed the presence of alkaloids, flavonoids, tannin and sterols. Gomez et al. [15] and Navarro et al. [16] speculated that the anti-inflammatory activity of these compounds is markedly influenced 
by the inhibition of neutrophil migration into inflamed tissue. Moreover, alkaloids flavonoids and saponins have been found in other natural products with analgesic and anti-inflammatory properties $[16,17]$. Santos et al. [18] obtained antinociceptive effect of $\beta$-sitosterol isolated from Phyllanthus corcovadensis which supports the potent analgesic and anti-inflammatory activities of $C$. suffruticosa due to the alkaloids, flavonoids and other polyphenols present in its alcoholic extract. Further studies, obviously, will clarify the mechanisms of action underlying the effects of extract and their active compounds. However, this is the first scientific basis on the use of this plant as a good source of analgesic and anti-inflammatory action.

\section{Acknowledgement}

The authors wish to thank the Drug and Toxic Research Division, Fruits and Vegetables Research Division of Bangladesh Council of Scientific and Industrial Research (BCSIR) Laboratories, Chittagong, Bangladesh, for their continuous support during the progress of this research.

\section{References}

1. R. Koster and M. Anderson, E. J. Beer, Fed. Proc. 18, 412 (1959).

2. M. Gaertner, L. Müller, J. F. Roos, G. Cani, A. R. Santos, R. Niero, J. B. Calixto, R. A. Yunes, F. Delle Monache, and V. Cechinel-Filho, Phytomed. 6, 41 (1999). PMID:10228610

3. G. Woolfe and A. D. Macdonald, J. Pharmacol. Exp. Ther. 80, 300 (1944).

4. T. L. Yaksh, J. Clin. Pharmacol. 21, 334S (1981). PMID:6895380

5. C. A. Winter, E. A. Risley, and G. W. Nuss, Proc. Soc. Exp Biol. Med. 111, 544 (1962).

6. O. A. Olajide, S. O. Awe, J. M. Makinde, A. I. Ekhelar, A. Olusola, O. Morebise, and D. T. Okpako. J. Ethnopharmacol. 71, 179 (2000). doi:10.1016/S0378-8741(99)00200-7

7. T. B. Nguelefack, A. L. Fotio, P Watcho, S. L.Wansi, T. Dimo, and A. Kamanyi, Phytother. Res. 18, 386 (2004). http://dx.doi.org/10.1002/ptr.1444

8. C. W. Murray, F. Porreca, and A. Cowan, J. Pharmacol. Met. 20, 182 (1988). http://dx.doi.org/10.1016/0160-5402(88)90078-2

9. A. Tjolsen, O. G. Berge, S. Hunskaar, J. H. Rosland, and K. Hole, Pain 51, 12 (1992). doi:10.1016/0304-3959(92)90003-T

10. Y. F. Chen, H. Y. Stai and T. S. Wu, Planta Med. 61, 5 (1995). http://dx.doi.org/10.1055/s-2006-957987

11. F. H. Do Monte, J. G. Jr dos Santos, M. Russi, V. M. Lanziotti, L. K. Leal, and G. M. Cunha, Pharmacol. Res. 49, 241 (2004). http://dx.doi.org/10.1016/j.phrs.2003.10.002 PMid:14726218

12. F. V. Abott and S. N. Young, Pharmacol. Biochem. Behaviours 31, 858 (1988). doi:10.1016/0091-3057(88)90395-4

13. M. Di Rosa, J. P. Giroud, and D.A. Willoughby, J. Pathol. 104, 15-29 (1971). http://dx.doi.org/10.1002/path.1711040103 PMid:4398139

14. Y. L. Ho, K. C. Kao, H. Y.Tsai, F. Y. Chueh, and Y. S. Chang, The Ame. J. Chinese Med. 31, 66 (2003). DOI: 10.1142/S0192415X03000783

15. F. Seanatore, A. Mścisz, K. Mrugasiewicz and P. Gorecki, Boll. Soc. Ital. Biol. Sper. 65, 139 (1989). PMID:2751881

16. M. A. Gómez, M. T. Sáenz, M. D. García, and M. A. Fernández, Z. Nat. 54, 939 (1999). PMID:10627992 
17. A. Navarro, B. De Las Heras, and A. Villar, Biol. Pharm. Bull. 24, 471 (2001). http://dx.doi.org/10.1248/bpb.24.470

18. A. R. Santos, R. Niero, V. C. Filho, R. A. Yunes, M. G. Pizzolatti, F. D. Monache, and J. B. Calixto, Planta Med. 61, 331 (1995).

http://dx.doi.org/10.1055/s-2006-958093 PMid:7480179

11. F. H. Do Monte, J. G. Jr dos Santos, M. Russi, V. M. Lanziotti, L. K. Leal, and G. M. Cunha, Pharmacol. Res. 49, 241 (2004). http://dx.doi.org/10.1016/j.phrs.2003.10.002 PMid:14726218 